\title{
Pengaruh Drainase Terhadap Lingkungan Jalan Mendawai dan sekitar Pasar Kahayan
}

\author{
Novrianti \\ Program Studi Teknik Lingkungan Universitas Muhammadiyah Palangkaraya \\ email:vnovrianti@yahoo.co.id
}

\begin{abstract}
ABSTRAK. Dua tahun terakhir Kota Palangka Raya sering mengalami banjir, terutama saat hujan dengan durasi dan curah hujan cukup tinggi. Daerah permukiman pasar Kahayan merupakan salah satu kawasan yang mengalami banjir tersebut disertai pencemaran lingkungan. Kondisi ini disebabkan buruknya kondisi saluran drainase. Limbah domestik dan industri yang dihasilkan dari Kawasan Pasar Kahayan masuk ke dalam saluran drainase Primer dan mengalirkannya Sungai Kahayan, sehingga mencemari sungai dan drainase permukiman di sekitarnya. Permasalahan pencemaran lingkungan yang disebabkan saluran drainase ini menimbulkan pertanyaan apa dan bagaimana pengaruh saluran drainase yang kurang baik terhadap pencemaran lingkungan permukiman di sekitar Kawasan Pasar Kahayan. Berdasarkan pertanyaan tersebut, penelitian ini bertujuan mengkaji pengaruh saluran drainase di Kawasan Pasar Kahayan, Kota Palangka Raya terhadap pencemaran lingkungan permukiman di sekitarnya. Metode analisis yang digunakan adalah metode deskriptif kualitatif, dengan wawancara dan observasi lapangan untuk pengumpulan datanya. Dari hasil analisis, diketahui bahwa kondisi saluran drainase yang cukup baik, seperti bangunan saluran yang sudah terbuat dari pasangan batu berbentuk trapezium tetapi saluran tersebut dipenuhi sampah sehingga menyebabkan aliran dari saluran drainase industri dan permukiman bertemu di satu titik dan langsung menuju ke arah aliran drainase yang sama yaitu sungai-sungai di sekitar Kawasan Pasar Kahayan. Akibatnya, air pada saluran drainase yang telah tercemar mencemari air dan tanah di kawasan permukiman di sekitar kawasan tersebut, termasuk sumber mata air. Kondisi ini terjadi juga karena infiltrasi air dimana masuknya atau meresapnya air dari permukaan tanah tercemar ke dalam bumi. Kesimpulan penelitian ini adalah bahwa kondisi saluran drainase cukup baik tetapi perlunya dilakukan pembersihan secara kontinu dan adanya sosialisasi agar masyarakat yang kurang sadar dapat mengubah pemikirannya.
\end{abstract}

Kata kunci : saluran drainase, pencemaran kawasan pasar kahayan

\section{PENDAHULUAN}

Banjir merupakan fenomena alam ketika sungai tidak dapat menampung limpahan air hujan karena proses influasi mengalami penurunan. Itu semua dapat terjadi karena hijauan penahan air larian berkurang. Dampak: ganggungan kesehatan, penyakit kulit, aktivitas manusia terhambat, penurunan produktifitas pangan, dll.

Kekeringan adalah kekurangan air yang terjadi akibat sumber air tidak dapat menyediakan kebutuhan air bagi manusia dan makhluk hidup yang lainnya. Dampak: menyebabkan ganggungan kesehatan, keterancaman pangan. 
Pada dasarnya, saluran drainase perkotaan adalah salah satu prasarana yang berperan sebagai pengering dan pengalir air hujan dari suatu wilayah perkotaan, yang meliputi pemukiman, kawasan industri dan perdagangan, sekolah, rumah sakit, lapangan olahraga, lapangan parkir, instalasi militer, instalasi listrik dan telekomunikasi, pelabuhan udara, pelabuhan laut, serta tempat-tempat lainnya yang merupakan bagian dari sarana kota. Saluran drainase berfungsi mengendalikan kelebihan air permukaan, sehingga tidak menimbulkan dampak negatif, seperti banjir. Dengan demikian, saluran drainase dibangun untuk dapat memberikan manfaat bagi kegiatan kehidupan manusia secara umum.

Karena fungsinya yang bersifat mengalirkan air pada kawasan terbuka, air yang masuk ke dalam saluran drainase harus bersifat tidak berbahaya dan tidak menyebabkan terjadinya pencemaran lingkungan. Air buangan yang berasal dari rumah tangga atau sarana umum yang lain yang tidak berbahaya dan tidak mencemari dapat langsung dibuang di saluran drainase. Tetapi air limbah yang berasal dari kegiatan industri yang berpotensi mencemari lingkungan, sebelum masuk ke saluran drainase, harus diolah dahulu sedmikian rupa, sehingga tidak akan mencemari. Hanya air yang telah memenuhi baku mutu tertentu yang dapat dimasukkan ke saluran drainase saja, sehingga tidak merusak lingkungan (Suripin, 2004). Pada umumnya, permasalahan saluran drainase adalah masuknya air limbah yang berbahaya dan mencemari yang berasal dari sumber pembuangan, khususnya dari kegiatan domestik dan industri. Akibatnya, saluran drainase tersebut membawanya masuk ke dalam kawasan publik, seperti kawasan permukiman, dan mencemari lingkungan di kawasan tersebut. Air yang tercemar yang masuk ke dalam saluran drainase akan semakin mudah mencemari lingkungan apabila ditunjang oleh kondisi saluran drainase yang buruk. Kondisi fisik saluran drainase yang masih berupa tanah akan memudahkan air merembes masuk ke dalam tanah. Akibatnya, bahan tercemar yang terkandung di dalam air tersebut masuk ke dalam tanah dan mencemari tanah tersebut.

Hal tersebut sering terjadi salah satunya di Kota Palangka Raya, dimana beberapa tahun terakhir terjadi banjir dibeberapa tempat, dapat dipengaruhi karena luapan air dari daerah hulu, ataupun karena pengaruh drainase yang belum memadai, dan kurang terpelihara. Salah satu permasalahan tersebut terjadi di Sekitar Pasar Kahayan Kota Palangka Raya, pada kondisi saluran drainase di sekitar Kawasan Pasar Kahayan Kota Palangka Raya. Masuknya alir limbah yang tercemar ke dalam saluran drainase dikawasan tersebut terlihat dari warna air dan dinding saluran yang hitam, keruh, dan berbau tidak sedap. Keadaan tersebut sangat mengganggu aktivitas dan kesehatan masyarakat disekitar Kawasan Pasar Kahayan. Pencemaran saluran drainase tersebut disebabkan oleh sampah dan limbah yang dibuang ke saluran Primer yang tidak dikelola dengan baik, sehingga mencemari saluran drainase di sekitar kawasan tersebut. Sehingga pengaliran air tidak dapat berfungsi dengan baik.

\section{TUJUAN PENELITIAN}

Tujuan dari penelitian ini adalah mengkaji pengaruh saluran drainase di Kawasan Pasar Kahayan terhadap pencemaran lingkungan permukiman di sekitarnya. Untuk mencapai tujuan tersebut, penelitian ini memiliki beberapa sasaran, yaitu mengkaji kondisi dan fungsi saluran drainase di Kawasan Pasar Kahayan; mengkaji pengaruh saluran drainase yang terjadi di Kawasan Pasar Kahayan; dan mengkaji penyebab terjadinya pengaruh saluran drainase terhadap pencemaran lingkungan permukiman di sekitar Kawasan Pasar Kahayan.

\section{MANFAAT PENELITIAN}

Manfaat penelitian ini adalah mengetahui kondisi dan fungsi saluran drainase di Kawasan Pasar Kahayan; mengetahui pengaruh saluran drainase yang terjadi di Kawasan Pasar Kahayan; dan mengetahui penyebab terjadinya pengaruh aluran drainase terhadap pencemaran lingkungan permukiman di sekitar Kawasan Pasar Kahayan. 


\section{KAJIAN PUSTAKA}

Drainase merupakan salah satu fasilitas dasar yang dirancang sebagai sistem guna memenuhi kebutuhan masyarakat dan merupakan komponen penting dalam perencanaan kota (perencanaan infrastruktur khususnya). Menurut Suripin (2004) drainase mempunyai arti mengalirkan, menguras, membuang atau mengalihkan air. Secara umum drainase didefinisikan sebagai serangkaian bangunan air yang berfungsi untuk mengurangi dan atau membuang kelebihan air dari suatu kawasan atau lahan, sehingga lahan dapat difungsikan secara optimal. Sistem jaringan drainase perkotaan umumnya dibagi atas 2 bagian, yaitu sistem drainase makro dan sistem drainase mikro, sedangkan saluran drainase dibedakan menjadi 3 bagian yaitu saluran drainase primer, saluran drainase sekunder dan saluran drainase tersier (Ayu dkk, 2013 dalam Novrianti, 2015).

Walaupun hubungan curah hujan dan limpasan tidak di definisikan dengan baik, limpasan biasanya naik sebanding dengan curah hujan pada dataran drainase (Sutanto, 2006). Teknik yang digunakan dalam penentuan narasumber dalam wawancara menggunakan teknik purposive sampling. Teknik ini merupakan teknik pengambilan sampel yang digunakan jika seorang peneliti memiliki pertimbangan tertentu dalam pengambilan sampelnya atau terdapat tujuan tertentu dalam pengambilan sampelnya (Riduan, 2008).

\section{METODE PENELITIAN}

\section{Lokasi Penelitian}

Lokasi penelitian dipusatkan di Tjilik Riwut Kawasan Pasar Kahayan dan sekitarnya.

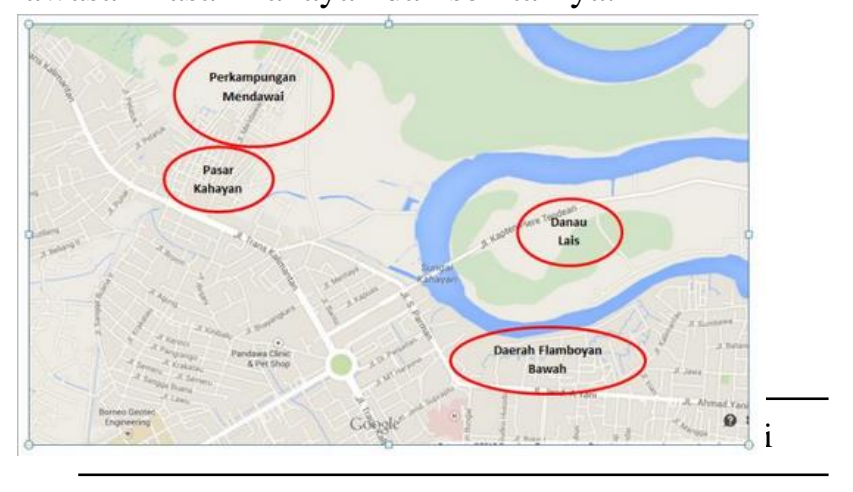

Jalan mendawai

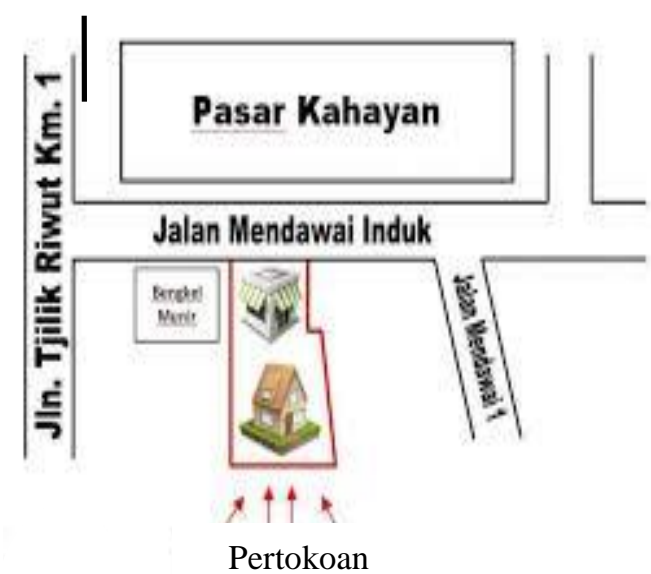

Gambar 2. Lokasi penelitian

\section{Metode Analisis}

Metode analisis yang akan digunakan dalam merumuskan hasil penelitian pengaruh kondisi saluran drainase pada permukiman disekitar Kawasan Pasar Kahayan adalah Analisis tematik secara historis praktik konvensional dalam penelitian kualitatif yang melibatkan pencarian melalui data untuk mengidentifikasi pola berulang. Tema adalah sekelompok kategori terkait menyampaikan makna yang sama dan biasanya muncul melalui proses analisis induktif yang menjadi ciri paradigma kualitatif.

Dalam penelitian ini, teknik ini digunakan untuk menentukan narasumber yang memiliki pengetahuan lebih mengenai objek penelitian, mengenai pengaruh saluran drainase terhadap pencemaran lingkungan sekitar Kawasan Pasar Kahayan. Terkait dengan beberapa instansi, maka narasumber merupakan perwakilan Bappeda Kota Semarang, Dinas PSDA, BLH, Kelurahan/Kecamatan, pengelola kawasan industri, pihak swasta, serta perwakilan dari masyarakat. Penggunaan analisis ini yaitu dengan pengkodean (coding) istilah-istilah atau kata yang terkait dan relevan dengan isu penelitian, yang sering muncul dalam media komunikasi. Dalam pengkodean (coding), perlu dicatat konteks dimana kata tersebut muncul. Setelah terdapat kata-kata kunci yang sering muncul dalam media komunikasi, kemudian dilakukan klasifikasi terhadap katakata kunci tersebut berdasarkan tingkat relevansi terhadap tujuan penelitian. Klasifikasi ini bertujuan untuk membangun 
kategori dari tiap hasil klasifikasi kata-kata kunci.

Pengkodean data ini akan mempermudah dalam proses analisis sehingga akan didapatkan informasi lebih lanjut dari kondisi, fungsi,penyebab dan dampak dari pencemaran saluran drainase diantaranya informasi tentang kelebihan dan kekurangan serta faktor yang menyebabkan pencemaran saluran drainase. Informasi tersebut selanjutnya dapat menjawab tujuan penelitian.

\section{Bagan Alir Penelitian}

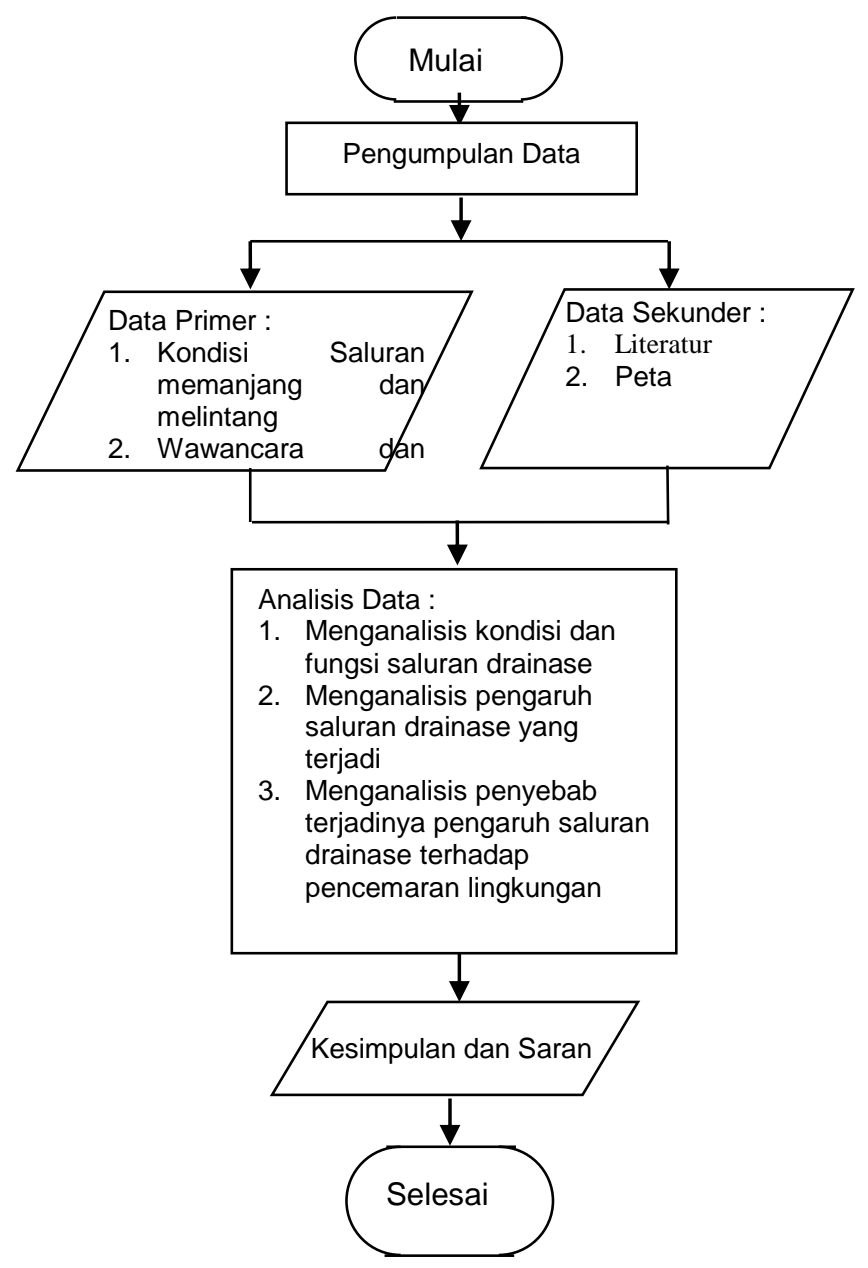

Gambar 3. Bagan Alir Penelitian

\section{BATASAN MASALAH PENELITIAN}

Lokasi penelitian dilakukan pada kawasan Pasar Kahayan dan sekitarnya

\section{HASIL DAN PEMBAHASAN}

Jaringan drainase yang terdapat di Kawasan Pasar Kahayan berupa jaringan primer, jaringan sekunder dan jaringan tersier.
Keadaan saluran drainase di kawasan tersebut kurang baik dilihat dari kondisi di lapangan. Saluran drainase di wilayah studi berupa saluran terbuka yang dihubungkan dengan sungai yang ada di sekitar kawasan tersebut. Saluran drainase yang terbuka tersebut hampir keseluruhan berada pada tepi jalan (sekunder) dan di depan rumah warga (tersier).Sedangkan pola jaringan yang terdapat di Kawasan Pasar Kahayan termasuk pola jaringan alamiah yakni saluran-saluran cabang yang ada langsung dikumpulkan ke saluran alamiah yaitu sungai. Penggunaan drainase sekaligus sebagai saluran pembuangan limbah industri dan limbah rumah tangga (sanitasi) menyebabkan terjadinya pendangkalan (sedimentasi) pada sungai ataupun saluran irigasi. Selain itu debit aliran sungai yang ada tidak mampu menampung laju aliran limpahan air hujan dari seluruh wilayah sekaligus, hal ini menyebabkan sering terjadi banjir di beberapa tempat.

Kawasan permukiman di sekitar Kawasan Pasar Kahayan mengalami pencemaran yang diakibatkan oleh sistem drainase yang buruk. Keberadaan kawasan Pasar yang tepat satu kawasan dengan kawasan permukiman penduduk tersebut seringkali memberikan masalah pencemaran lingkungan terutama permasalahan drainase. Pencemaran tersebut terjadi karena banyaknya limbah yang mengalir melewati saluran drainase tersier (drainase lingkungan permukiman). Sehingga air yang mengalir di saluran drainase menjadi keruh. Warga mengeluh karena sampah yang berserakan dan masuk ke dalam saluran drainase, padahal disediakan tempat sampah, dan melewati saluran drainase permukiman, sehingga cukup mengganggu bagi kesehatan warga di permukiman sekitarnya. Sedangkan rob terjadi karena adanya pengaruh luapan air hujan pada saat musim hujan, air mengalir kearah tempat yang lebih rendah (landai) kemudian air tersebut membendung dan menggenang yang diakibatkan oleh sampah yang menyumbat disaluran air. Sehingga pada saat hujan turun terjadilah banjir yang bercampur air pasang, sampah dan limbah dari aktifitas yang dilakukan di pasar dan 
sekitarnya sehingga menyebabkan tercemarnya saluran drainase di lingkungan permukiman sekitar Kawasan Pasar Kahayan. Jalan yang bergelombang dan berlubang juga ditemui di sekitar permukiman. Hal ini disebabkan dikarenakan seringnya muatan yang berlebihan dalam pengangkutan barang yang keluar masuk, sehingga menyebabkan genangan air akibat saluran drainase tersumbat dan tidak mampu menampung banyaknya debit air, maka sering terjadinya banjir di Kawasan tersebut, arah aliran air antara limbah industri dan limbah permukiman bertemu di satu titik dan mengalir ke tujuan yang sama yaitu sungai, dan pada wilayah studi.

Tanah yang rendah maka wilayah studi berpotensi mengalami penurunan tanah, karena kawasan tersebut difungsikan sebagai kawasan industri, pemukiman, serta perdagangan dan jasa sehingga beban tanah menjadi besar. Pencemaran itu terjadi karena adanya infiltrasi air, dimana pembuangan limbah masuk atau meresap ke dalam bumi. Infiltrasi tersebut tidak akan kembali atmosfer melalui proses evapotranspirasi melainkan air tersebut menjadi air tanah untuk seterusnya mengalir ke sungai disekitarnya. Maka dari itu terjadilah pencemaran sungai di sekita Kawasan Pasar Kahayan.

Dalam penelitian ini ditemukan beberapa pengaruh saluran drainase bagi permukiman di sekitar Kawasan Pasar Kahayan. Kondisi dan fungsi dari drainase di Kawasan tersebut kurang baik dilihat dari kondisi di lapangan. Saluran drainase di wilayah studi berupa saluran terbuka dan memiliki pola jaringan alamiah yakni saluransaluran cabang yang ada langsung dikumpulkan ke saluran alamiah yaitu sungai. Kondisi memprihatinkan terlihat di sekitar pasar Kahayan serta permukiman, karena kondisi air yang mengalir pada drainase di depan pekarangan warga mengganggu berwarna hitam, keruh, dan menimbulkan bau, sehingga bau yang ditimbulkan sangat mengganggu warga sekitar. Apalagi saluran drainase tersebut tidak berjalan dengan baik, karena tersumbat oleh sampah dari permukiman dan industri di sekitar permukiman tersebut.
Pencemaran saluran drainase tersebut mempengaruhi kondisi lingkungan permukiman di sekitar Kawasan Pasar Kahayan. Akibat dari kondisi drainase tersebut menyebabkan pencemaran saluran drainase permukiman, pencemaran itu terjadi karena banyaknya limbah dari aktifitas tersebut yang mengalir melewati saluran drainase tersier (drainase lingkungan permukiman), sehingga air yang mengalir di saluran drainase menjadi keruh. Pencemaran tersebut juga menimbulkan banjir rob dan jalan rusak. Dengan kondisi drainase yang tidak mengalir dengan baik, maka pada saat turun hujan air dari saluran drainase meluap hingga permukaan tanah, sehingga menyebabkan genangan air. Genangan air tersebut sedikit demi sedikit mengikis permukaan jalan, sehingga jalan menjadi mudah berlubang dan bergelombang.

Penyebab terjadinya pencemaran saluran drainase di lingkungan permukiman. Kawasan Pasar Kahayan adalah akibat sampah dan limba dari aktifitas di lokasi yang kurang diproses dengan baik dan arah aliran air antara limbah industri dan limbah permukiman. Saluran Primer drainase di Kawasan Pasar Kahayan tercemar, karena arus aliran saluran drainase dari arah Pasar Kahayan dan permukiman bertemu disatu titik, sehingga antara limbah dari Pasar Kahayan dan permukiman bercampur dan menyemari saluran-saluran drainase sekunder maupun tersier. Karena kawasan tersebut memiliki pola jaringan drainase alamiah, sehingga arah aliran dari saluran drainase Pasar Kahayan dan permukiman menuju ke arah aliran drainase yang sama yaitu ke arah sungai yang ada di sekitar Kawasan Pasar Kahayan. Serta adanya infiltrasi air yang menyebabkan kualitas air tanah juga kurang baik.

\section{KESIMPULAN}

1. Dari hasil penelitian kondisi saluran adanya sedimentasi, sampah baik pada saluran sekunder maupun saluran primer, dengan begitu fungsi dari saluran tersebut mengalami hambatan. Walaupun sudah disediakan tempat pembuangan sampah sementara (TPS), tetapi perilaku masyarakat sekitar Pasar Kahayan 
tetap melakukan buang sampah pada saluran sekunder dan primer.

2. Permasalahan yang terjadi yaitu pencemaran lingkungan yang diakibatkan oleh aktivitas manusia. Pencemaran drainase tersebut berupa air yang berwarna hitam, keruh, bau dan terjadi penyumbatan. Penyumbatan itu disebabkan karena adanya pembuangan limbah dari aktivitas masyarakat di Pasar Kahayan dan permukiman yang tidak dikelola dengan baik. Karena kawasan tersebut letak geografisnya ada di dataran rendah dan permukaan tanahnya sudah sangat landai sehingga rawan terjadi banjir dan rob.

3. Jaringan drainase yang terdapat di Kawasan Industri Genuk berupa jaringan primer, jaringan sekunder dan jaringan tersier. Sedangkan pola jaringan yang terdapat di Kawasan Industri Genuk termasuk pola jaringan alamiah yakni saluran-saluran cabang yang ada langsung dikumpulkan ke saluran primer yang menuju langsung ke sungai Kahayan. Sebagian besar jaringan drainase yang ada dalam kondisi yang memprihatinkan. Banyak saluran drainase yang tersumbat terutama di kawasan permukiman. Hal ini dikarenakan sistem pengaturan drainase yang kurang baik. Kondisi memprihatinkan terlihat di sekitar permukiman, karena kondisi air yang mengalir pada drainase di depan pekarangan warga berwarna hitam, keruh, dan menimbulkan bau, sehingga bau yang ditimbulkan sangat mengganggu warga sekitar. Berdasarkan penjelasan tersebut, dapat disimpulkan bahwa pencemaran saluran drainase di lingkungan permukiman sekitar Kawasan Pasar Kahayan terjadi akibat limbah dari aktivitas masyarakat di Pasar Kahayan yang mengalir melewati saluran drainase tersier (lingkungan permukiman) tidak dikelola dengan baik.

\section{SARAN}

1. Dari hasil kajian di beberapa lokasi tidak adanya drainase dan kurang terawatnya drainase yang ada, maka diperlukan pemeliharaan agar drainase di kawasan penelitian dapat mengalirkan air dan tidak menyebabkan genangan.

2. Perlunya di desain kembali debit aliran dan arah aliran agar dapat mengalir dengan baik.

3. Agar saluran drainase dapat berfungsi sebagaimana mestinya dalam kurun waktu yang lama, maka perlu diperhatikan masalah pemeliharaan dan normalisasi saluran tersebut dari pihak masyarakat dan dari dinas atau instansi yang berkaitan

\section{DAFTAR PUSTAKA}

Ayu. Ida, dkk. 2013. Analisis Kapasitas Saluran Drainase Sekunder.

Badan Meteorologi, Klimatologi dan Geofisika (BMKG) Propinsi Kalimantan Tengah, 2015, Data Hujan wilayah Palangka Raya. Palangka Raya.

Kodoatie, R.J. dan Roestam Sjarief. (2005). Pengelolaan Sumber Daya Air Terpadu.Yogyakarta: Andi Manik, Karden Eddy S. 2003. Pengelolaan Lingkungan Hidup. Jakarta : Djambatan

Novrianti, 2005, Kajian Drainase Terhadap Banjir Pada Kawasan Jalan Sapan Kota Palangkaraya, Media Ilmiah Teknik Sipil, Vo. 4 No. 1 Desember 2015. ISSN 0216 - 1346, ISSN 2407 3857 E. 2015

Standar Tata Cara Perencanaan Umum Drainase Perkotaan Departemen Pekerjaan Umum SNI : 02-2406-1991

Sofian, dkk. Perencanaan Teknis Drainase Kawasan Kasang Kecamatan Batang Anai Kabupaten Padang Pariaman. Jurnal Momentum. Vol. 14 no. 1 Februari 2013. ISSN: 1693-752X. 2014

Soemarwoto, Otto. 2001. Ekologi, Lingkungan Hidup dan Pengaruh Saluran Drainase Terhadap ... Frisca Fertrisinanda A.D.P dan Hadi Wahyono Teknik PWK; Vol. 1; No. 1; 2012; hal. 56-65 | 65

Suripin. 2004. Sistem Drainase Perkotaan yang Berkelanjutan. Andi Offset. Yogyakarta.

Sutanto, 2006, Pedoman Drainase Jalan Raya. Penerbit Universitas Indonesia. Jakarta

Triatmodjo. Bambang, 2010, Hidrologi Terapan, Cetakan Kedua, Beta Offset, Yogyakarta 